\title{
O distúrbio específico de linguagem em adolescente: estudo longitudinal de um caso ${ }^{* * *}$
}

\author{
Specific language impairment in adolescents: a follow-up case study
}

Debora Maria Befi-Lopes* (dmblopes@usp.br)

Amalia Rodrigues**

*Fonoaudióloga. Livre-Docente do
Curso de Fonoaudiologia da Faculdade
de Medicina da Universidade de São
Paulo (FMUSP). Professora Associada
do Departamento de Fisioterapia,
Fonoaudiologia e Terapia Ocupacional
da FMUSP.
**Fonoaudióloga. Doutoranda em
Semiótica e Lingüística Geral -
Faculdade de Filosofia, Letras e
Ciências Humanas da USP.
Fonoaudióloga do Curso de
Fonoaudiologia da FMUSP.
***Trabalho Realizado no Laboratório
de Investigação Fonoaudiológica em
Desenvolvimento da Linguagem e suas
Alterações do Curso de
Fonoaudiologia da FMUSP.

Artigo de Relato de Caso

Artigo Submetido a Avaliação por Pares

Conflito de Interesse: não

\begin{abstract}
Background: a follow-up study of an individual with Specific Language Impairment. Aim: to describe the oral and written language development of an adolescent during 13 years of intervention. Method: a male subject, 16 years old, in the second year of high school, who was assessed during the years with different language and auditory procedures. Results: the subject still presents oral and written language deficits, but these do not compromise intelligibility in any level. Conclusion: the studied subject presented significant language development during the therapeutic process. However, corroborating with other literature data, deficits still remain.
\end{abstract}

Key Words: Language Disorders; Language Developmental Disorders; Adolescent Development; Longitudinal Study.

\section{Resumo}

Tema: estudo longitudinal de um caso com Distúrbio Específico de Linguagem. Objetivo: descrever a evolução da linguagem oral e escrita de um adolescente ao longo de 13 anos de intervenção. Método: sujeito do sexo mausculino, 16 anos, segunda série do Ensino Médio, avaliado ao longo dos anos com procedimentos variados em linguagem e audição. Resultados: ainda apresenta alterações na linguagem oral e escrita, mas que não comprometem mais a inteligibilidade em nenhum dos níveis. Conclusão: o sujeito estudado apresentou evolução significativa da linguagem ao longo do processo terapêutico. Contudo, corroborando os dados da literatura não houve superação do quadro.

Palavras-Chave: Transtornos da Linguagem; Transtornos do Desenvolvimento da Linguagem; Desenvolvimento do Adolescente; Estudo Longitudinal.

Recebido em 24.08.2004.

Revisado em 15.03.2005; 2.05.2005;

5.07.2005.

Aceito para Publicação em 5.07.2005. BEFI-LOPES, D. M.; RODRIGUES, A. Specific language impairment in adolescents - a follow-up case study (original title: O distúrbio específico de linguagem
em adolescente - estudo longitudinal de um caso). Pró-Fono Revista de Atualização Científica, Barueri (SP), v. 17, n. 2, p. 201-212, maio-ago. 2005. 


\section{Introduction}

Literature about Specific Language Impairment (SLI) usually focus on transversal studies. A little is known about how language develops in those children and if the acquisition process occurs following the same stages as those observed in children with normal development, or if it follows idiosyncratic ways leading to atypical language patterns.

The SLI refers to a primary language disorder that occurs in the absence of: hearing loss, speech cognitive and motor development alterations, syndromes, broad development disorders, sensorineural disorders, and acquired neurological lesions, and that impede the expected language development (Befi-Lopes, 2004; Castro-Rebolledo et al., 2004). It is a condition which the language difficulties persist through life (Gandara, 2004).

The linguistic manifestations of SLI vary, however, generally it can be observed the use of developmental and idiosyncratic phonological processes (Befi-Lopes \& Palmieri, 2000); poor vocabulary (Befi-Lopes, 1997), fewer number of communicative intentions (Bishop et al., 2000), and deficits in the morphologic and syntactic skills (Rice et al., 2004). Furthermore, children with SLI present worse performance in non-verbal cognitive skills, evidenced by the difficulty in the development of symbolic game (Befi-Lopes, Takiuchi \& Araújo, 2000a; 2000b).

The diagnosis of SLI is difficult once it would be restrict to the language abilities, and its detection would depend greatly on exclusion rather than inclusion criteria (Watkins, 1994; Takiuchi, 2004). However, some studies show that those children also present attention, motor functioning and academic deficits, and their learning difficulties would be related to the previous language problems (Catts et al., 2002; Young et al., 2002; Nathan et al. 2004b). Furthermore, when followed in longitudinal studies, it is observed that these subjects' linguistic profile changes and transits among the classification system by subgroups (Crespo-Eguílaz \& Narbona, 2003). The SLI is generally diagnosed in infancy, however the accompanying difficulties persist for the whole life, as demonstrate some researches that evaluated these subjects' communicative, social, cognitive, academic and behavioral skills

Johnson et al. (1999) performed a longitudinal and prospective study with 128 subjects with speech and language disorders, diagnosed at five years of age and re-evaluated at 12 and 19 years of age. The authors verified that the majority of the subjects with language disorders maintained the communication difficulties during adolescence. Stothard et al. (1998) followed children with speech and language disorders, diagnosed at 4 years of age until 15-16 years of age. The subjects who overcame their language difficulties until five years and six months of age presented similar performance to normal teenagers in the vocabulary and language comprehension tests, and deficits in the phonological processing and reading and writing tests. However, those who maintained the deficit after this age (5,6 years) presented bad performance in all tests. Laws \& Bishop (2003) also observed that adolescents with SLI presented greater deficits in expressive language and in grammar than in language comprehension and in vocabulary. Furthermore, they demonstrated great difficulty in grammatical morphology and phonologic memory tests.

Perhaps, one of the greatest questions for the speech-language pathologists would be to predict the prognosis of subjects with SLI in adolescence and adulthood from the skills observed in childhood. Aram, Ekelman \& Nation (1984) followed 20 adolescents with SLI for 10 years and verified that the preschool skills that better predicted the academic, social and linguistic success of these children were: IQ scores (non-verbal intelligence); language measures (mainly comprehension, grammatical formulation and repetition); reading and spelling level and the diadochocinetic repetition speed. For Botting et al. (2001), the story re-telling skills and the expressive syntax measures were the best prognostic indicators for children with SLI.

The majority of longitudinal studies investigate the reading and writing skills of this population, their academic success and the socioemotional difficulties due to the persistence of the disorder. Several researches agree that even in the adolescence, the performance of subjects with SLI in formal tests of oral and written languages is below their normal peers (Snowling et al., 2000; Briscoe et al., 2001), indicating that children with SLI diagnosed in the preschool period are of great risk for learning disorders, which stresses the intervention need as soon as possible (ContiRamsden et al., 2001; Catts et al., 2002; Young et al., 2002).

Bishop \& Clarkson (2003) observed that mainly the grammatical and phonological factors affect 
the written language development of children with SLI. Subjects presented imitations in the grammatical structure of sentences, spelling mistakes, unintelligible writing, orthographic processing deficit, poor semantic content, grammatical mistakes, accentuation difficulties, and poor performance in tasks of non-words repetition. The authors also verified a positive correlation between the performance in the written language tests and the phonological memory tests, and suggest that the deficits in phonological processing tasks would be the main cause of reading and writing difficulties in this population.

The persisting oral language problems and reading and writing acquisition and development difficulties may be associated to significant educational problems that reduce the possibility of these subjects to reach the expected academic level (Nathan et al., 2004a). In addition to the communication and academic problems, Beitchman et al. (2001) and Jerome et al. (2002) stress the need for early psychiatric intervention for subjects with SLI, once these adolescents demonstrate psychiatric disorders, such as anxiety, social phobia, and personality disorders throughout the years. Moreover, several authors associate the SLI to behavioral and social difficulties (Redmond \& Rice, 2002). For Conti-Ramsden \& Botting (2004), the majority of adolescents with SLI aging 11 years old present emotional difficulties, social isolation, behavior problems, difficulties in relating to peers (such as few friends and problems in making new friends) and some become target victims in the school environment. The authors didn't find significant correlations between the individual aspects of language and the social and behavioral measures, with the exception of the poor pragmatic skills. Befi-Lopes, Rodrigues \& Rocha (2004) have also observed discursive difficulties presented by children with SLI, such as inappropriate responses to the adult interlocutor's questions and significant use of unintelligible responses. According to the authors these results facilitate the understanding of the interference of the communicative profile of these subjects on the socialization development.

This research aims at presenting a longitudinal study about the acquisition of some formal language aspects of an adolescent with SLI followed in our service during 12 years.

\section{Method}

The study patient and his legal guardian permitted the performance of this research, as well as the publication of the results, signing the informed consent term.

\section{Subject}

R.O.M., 16 years of age, male, presents SLI diagnosed at the Speech-Language Laboratory on Language Development and its Disorders of the Speech and Hearing Course - Medicine School of University of São Paulo in consonance with the normal neurological evaluation; with a psychological evaluation that disregarded the possibility of mental retardation; and normal hearing evaluation.

\section{Material}

The material used for each evaluation of the subjects' linguistic skills will be described below, together with the year of the evaluation, once some tests were modified or substituted during the speech-language intervention:

. 1991 - Initial Evaluation: Anamnesis (Lins \& Braga, 1985) and Language Informal Evaluation by the use of a ludic interaction;

.1994 - Naming Task and Figure Identification task, Articulation and Fluency test, and Oral sensorymotor system evaluation (Lins \& Braga, 1985);

. 1997 - Phonology Test using Naming of figures and words Imitation (Wertzner, 1992); Oral Narrative Production task using visual stimulus, Written Language task comprising the copy of sentences, reading and text comprehension, and text composition from a theme, Oral sensory-motor system evaluation, Figures Identification and Naming, and Fluency test (Lins \& Braga, 1985); . 2000 - Phonology Tests, Expressive Vocabulary (Befi-Lopes, 1997), Pragmatics and Fluency (Andrade et al.,2000); Oral sensory-motor system evaluation, Oral Narrative production task with the use of visual stimulus, Written Language test composed by sentence production from a target word, reading and text comprehension and dictation (Fernandes et al., 1998) and Motor Praxis evaluation (Rodrigues, 1999);

. 2003 - Phonology test (Wertzner, 2000); Motor Praxis evaluation (Rodrigues, 1999); Auditory Discrimination task, Phonological Awareness task, Oral Narrative production task with the use of visual stimulus, and Written Language test composed by sentence production from a target word, reading, and text and dictation comprehension (Fernandes et al., 1998). Besides the standardized tasks, in this 
occasion a phonological memory evaluation was elaborated (repetition of non-words.;

. 2004 - Auditory Discrimination task (Fernandes et al., 1998) and Phonology test (Wertzner, 2000).

\section{Procedures}

All hearing and language evaluations, performed during the speech-language rehabilitation process, since the diagnosis (at 3:5 years of age) until the present period (15:11 years of age) were analyzed. The every year re-evaluation practice is adopted in the Laboratory as a way to optimize the therapeutic process, considering specific aspects that may facilitate the language development of our patients and make the dyad therapist-patient more effective. Furthermore, considering the literature (Crespo-Eguílaz \& Narbona, 2003; Laws \& Bishop, 2003), the changes in the linguistic manifestations during the intervention of children with SLI make this procedure quite obligatory, when we aim at the effectiveness of the rehabilitation process; after a period far from the therapy (vacation, for example), the linguistic performance of these children is similar to the one presented in the period before, demanding, then, substantial changes in the rehabilitation conducting. This way, every beginning of the year this patient, as well as all other patient attending the Laboratory, go through a language evaluation process when there is the confirmation of the acquired behaviors, of the overcome and persisting difficulties and if there are new matters that need to be addressed. Obviously, the acquired and overcome behaviors are not re-evaluated after the confirmation, either in the evaluation as in the functional use (that's why it is important to make therapeutic recordings), and aspects that were not evaluated yet are added in the evaluations. The recordings of the subject's performance during the speech-language therapies were also used. The reading and writing evaluation and development recordings will be mentioned only after 1997 , when the child attended the third grade of the basic cycle; before this period, he didn't present writing.

\section{Results}

The authors of this paper chose to describe the hearing and language evaluations every three years of speech-language intervention in order to avoid excessive redundant information, jeopardizing the aim of the study. Therefore, the results will be presented the following way: firstly the data from the evaluation of the diagnostic period and, then, the language re-evaluations every three years (years 1994; 1997; 2000 and 2003). The year 2004 will also be described due to the significant changes related to the oral language.

1991 - Initial evaluation - age 3:5 years

Initial interview

R.O.M. was taken to the Speech-Language Service referred by a pediatrician. The mother's complaint was: "he doesn't speak properly and is very nervous". In the historic, there was no gestational, pre, peri or post-natal intercurrences. The neural-psycho-motor development was normal.

Concerning the emerging of oral language, the mother reported that the first words were produced at 11 months old, always presenting substitutions, and that if the child didn't understand he got nervous, screamed and hit his head on the wall (sic).

Speech-language evaluation

It was performed in a ludic interactive situation, once R.O.M. didn't respond to any formal evaluation. In that occasion, he demonstrated good oral language comprehension in contextualized situations, reduced vocabulary, naming of objects be their functions or unintelligible segments production. He didn't produce even simple sentences.

At that time it wasn't possible to evaluate the phonology, once R.O.M. presented an extremely reduced and instable phonetic inventory. In the phonemic production analysis, it was observed: systematic omission of liquids, archiphonemes, velar fricatives and consonantal clusters, besides the velar plosive /g/, and bilabial /p/, and fricatives /S//z//z/; unsystematic omission of nasal phonemes and other fricatives - /f/ /s/ /v/, with occasional substitution for $/ \mathrm{t} /$. It was not possible to evaluate the speech and fluency, once he didn't present emissions that could be analyzed.

Concerning the pragmatics it was observed good communicative intention, predominantly vocal, with the use of a few gestures, making difficult the communication with him, once his oral productions were mostly unintelligible.

Concerning the oral sensory-motor system, he presented oral breathing, hypotonic lips, tongue 
and cheeks, besides the mobility and resting position alterations and a constant saliva flow.

The hearing was normal in both ears.

$$
1994 \text { - Age 6:7 years }
$$

In this occasion R.O.M. presented substantial improvements, although his language profile was yet very altered. The receptive and expressive vocabulary, evaluated through formal tasks (Lins \& Braga, 1985), presented significant improvements: $89 \%$ of correct responses for the receptive and $75 \%$ for the expressive vocabulary.

The phonology evaluation, also through formal tasks (Lins e Braga, 1985), presented improvement once the use of phonological processes was stable; even though they occurred in great number, it was possible to have a better understanding of his oral productions once they occurred systematically: plosive and fricative devoicing, fricative plosivation - /s/, /S/ and /z/ for /t/; simplification of liquids, consonantal clusters and final consonants, substitutions of vowels in the final syllable - /o/ for /i/.

In the discourse evaluation (Lins \& Braga, 1985) he didn't present spontaneous production limiting to respond to the examiner's questions about the figure he should name. Concerning the syntax, he presented simple sentences production (subject +verb +object) without using subordination or coordination. Concerning the pragmatics, evaluated through the interaction during therapy, he kept good communicative intention, predominantly vocal (productions with less than $75 \%$ of the phonemes of the correctly produced words), however intelligible. The fluency observation presented non-stuttered disfluency clearly marked by failures in the lexical access. Regarding the oral sensory-motor system (Lins \& Braga, 1985) no improvements were observed, except from reduction of the saliva flow.

1997 - Age 9:7 years

In this time, the expressive vocabulary of R.O.M. matched his reality and world knowledge, although he presented significant difficulties with polysemous words; once these words do not occur in a significant number, they didn't compromise his understanding in daily or school situations.

In the formal evaluation of phonology (Lins \& Braga, 1985), performed through imitation and naming tasks, R.O.M. presented the processes of: plosives and fricatives devoicing; liquids, consonantal cluster and final consonant simplification; backing for palatal with $100 \%$ of occurrence. The speech was descriptive with the use of simple sentences, limiting to describe what he visually observed in the figure-stimulus (Lins $\&$ Braga, 1985). The pragmatics was still adequate concerning the communicative function and the communicative intention, however predominantly verbal now, facilitating R.O.M.'s productions understanding. Concerning the fluency (Lins \& Braga, 1985), no stuttering episodes were observed, but the non-stuttered disfluency due to failures in the lexical access remained, although in reduced number. In the oral sensory-motor system evaluation (Lins \& Braga, 198\%) it was observed oral-nasal breathing, altered tonus and mobility of lips and tongue, open lips and tongue positioned on the floor of the mouth at rest, besides altered chewing and swallowing patterns.

At this time, R.O.M. was at the third grade of a public school with automatic approval since the first grade. His reading proficiency was practically absent, with clear text comprehension difficulties, even the simple ones. He also presented writing elaboration and organization difficulties without cohesive elements, incomplete sentences, short productions, he didn't produce narratives, only descriptive texts with daily life themes and jeopardized coherence. His productions presented failures in vocabular limit, in orthographic rules and memory, in accentuation and punctuation.

Concerning the hearing, it was possible to perform the auditory processing evaluation that revealed the following results: hearing thresholds and immitance measures within normal limits in both ears, mild auditory processing alteration in the PSI test (figure-ground skill), in non-verbal dichotic test and in digit dichotic test. Eight sessions of the altered abilities auditory training were suggested, followed by a re-evaluation.

\section{0 - Age: 12 years and 7 months}

The expressive vocabulary was evaluated through the Expressive Vocabulary Verification Test (Befi-Lopes, 2000): the lexical performance of the subject was similar to the one observed in 1997. The oral sensory-motor system evaluation (Fernandes et al., 1998) was the same as the 1997 re-evaluation, except from the correction of the resting position of the lips. In the evaluation of the Bucco-facial Praxis Skills (Rodrigues, 1999) he was incapable of performing some movements even with visual and tactile cues (for example: when 
asked to narrow the tongue, R.O.M. inflated the cheeks with air. He was also unable to perform some tongue movements without the dissociation of mandibular movements). In the Narrative Production (Fernandes et al., 1998) he presented: short productions with low syntactic complexity; difficulties in the global organization of the story and in describing the events in a temporal sequence; use of a few cohesive elements; introduction of irrelevant information, difficulty in introducing and re-introducing the characters; and more facility to report the initial event rather than the conclusion.

The phonology was evaluated through the Phonology Test of naming and imitation from the test ABFW (Wertzner, 2000). In the naming task, he presented the following phonological processes: palatal fronting (40\%); consonantal cluster simplification (100\%); final consonant simplification (60\%); plosives devoicing (100\%); and fricatives devoicing (100\%). In the imitation task, he presented: liquid simplification $(28,6 \%)$; consonantal cluster simplification (100\%); final consonant simplification $(14,3 \%)$; plosives devoicing $(66,7 \%)$ and fricatives devoicing $(88,9 \%)$.

Concerning reading and writing (Fernandes et al., 1998) the performance was the same as in 1997, except from a slight improvement in the textual comprehension.

In the Central Auditory Processing evaluation, he presented results within normal limits.

\section{3 - Age: 15 years e 7 months}

Great improvement was observed in the auditory discrimination, once he was able to realize the distinction between devoiced and voiced fricative phonemes $(/ \mathrm{z} / \mathrm{e} / \mathrm{v} /)$ and in the vibrant liquid $/ \mathrm{R} /$, , in the consonantal clusters, in the vibrant archiphoneme $(\{R\})$. He maintained the discrimination difficulty in the other voiced phonemes (specially the plosives) and in the palatal liquid. He also demonstrated improvement in the bucco-facial praxis skill, being able to perform some movements without needing help and visual and tactile stimulation, reflecting the articulatory production of some sounds that were previously omitted or substituted. However, he maintained great articulatory difficulties with the voiced phonemes (/z/ e /Z/), the liquids (lateral and vibrant), the consonantal clusters (groups /R/ and $/ 1 /$ ), the devoiced palatal fricative (/S/), although he produced in isolated activities the archiphoneme $\{\mathrm{R}\}$ and the lateral liquid $(/ \mathrm{l} /)$.
In the Naming task of the Phonology Test (Wertzner, 2000), he presented the following phonological processes: palatal fronting $(80 \%)$; liquids simplification $(18,2 \%)$; consonantal cluster simplification (100\%); final consonant simplification (20\%); plosives devoicing $(50 \%)$ and fricatives devoicing $(67 \%)$. In the imitation task he presented: palatal fronting (17\%); liquids simplification $(14,3 \%)$; consonantal cluster simplification (100\%); plosives devoicing $(27,8 \%)$ and fricatives devoicing $(66,7 \%)$. The Percentage of Correct Consonants (PCC) in the Imitation task was $74.4 \%$ and in the Naming task, it was $79.4 \%$, indicating a mild-moderate phonological disorder. The Process Density Index (PDI) was 0,82 in the Imitation task and 0,64 in the Naming task (Wertzner et al., 2001; Wertzner \& Galea, 2002).

In that occasion, a phonological memory evaluation was elaborated through repetition of non-words and R.O.M. presented a good performance in disyllables, trissyllables and polysyllables non-words repetition (90\% of correct responses). In phonological awareness tasks (Fernandes et al., 1998) he presented great performance in rhyme, alliteration, syllabic manipulation and transportation. In spelling, he presented difficulties in words with voiced phonemes (fricatives and plosives) and in complex syllables with consonantal cluster and archiphoneme $\{\mathrm{R}\}$. Furthermore, he demonstrated decline in the spelling performance with the increase of the word extension (polysyllables). $\mathrm{He}$ couldn't perform activities involving phonemic segmentation. The narrative production (Fernandes et al., 1998) was the same as in 2000.

Concerning the reading and writing (Fernandes et al., 1998) he demonstrated textual comprehension difficulties (specially with inferences) and text organization difficulties (short sentences; little use of subordination and coordination; difficulty in the logical-temporal sequencing organization, jeopardizing the textual coherence; preference for writing descriptive texts; incomplete sentences production; absence of plural in substantives; and verbal concordance mistakes regarding the number and the past tense using only the present tense and the singular). Regarding the typology of mistakes in the writing, it was observed great improvement related to the phonological mistakes, once they were only a few in his written production. The alterations of phonological origin were represented by the substitution of the grapheme $\mathrm{x} / \mathrm{ch}$ and $\mathrm{j}$ for the graphemes $\mathrm{s}$ and $\mathrm{z}$; omission of the graphemes $r$ and 1 ; omission of all consonantal 
cluster with $\mathrm{R}$ e L, omission dos graphemes $\mathrm{R}$ and $S$ in the end of the syllable, and substitution of the graphemes b, d, g, v, z, s in intervocalic position and $\mathrm{j}$ by the graphemes $\underline{\mathrm{p}}, \underline{\mathrm{t}}, \underline{\mathrm{c}}, \underline{\mathrm{f}}, \underline{\mathrm{s}}, \underline{\mathrm{x}}$, respectively. He also presented hearing cues valuing mistakes, orthographic rules and memory problems. It was observed improvement in the reading speed, however with difficulty in irregular words reading with /e/ and /o/ in a tonic paroxyton position.

In the peripherical hearing evaluation, he presented normal pure tone hearing thresholds, except in the frequency of $8000 \mathrm{~Hz}$ in the right ear, timpanometry type $\mathrm{A}$ in both ears and elevated acoustic reflexes in the right ear. In the behavioral and Electrophysiological tests of the Auditory Processing, he presented normal results in the sequential memory, figure-ground, auditory closure, directed attention, duration pattern and in the absolute latencies of ABR. He presented alteration in the frequency pattern $(\mathrm{RE}=64 \% \mathrm{LE}=$ $44 \%)$ and ear effect (C4 for RE). Normal latencies and altered morphological aspect in P300. He underwent clinical neurological evaluation and tomography presenting normal results.

Writing hypothesis elaborated by the subjects during the therapies

From the improvement in the auditory discrimination, in the articulatory production and in the phoneme-grapheme association, R.O.M. elaborated and verbalized during therapy three hypothesis on writing. First Hypothesis: "if the letter is changed, the sound changes and the understanding changes" (ex: if for vaca you write faca or if for rata you write lata). Second Hypothesis: "if the letter is changed and the sound and the understanding are not, the word is wrong. So, what to do to know the which is right? (ex: if for fichário you write fixário or if for gelo you write jelo). Third Hypothesis: "if the letter is changed and the sound is changed, can it form a word that does not exist?" (ex: if for chute you write sute or if for perto you write peto).
2004 - Age: 15 years and 11 months

He presented improvement in the auditory discrimination (Fernandes et al., 1998) and nowadays he realizes the distinction between voiced and devoiced fricative and plosive. The phonology performance (Wertzner, 2000) is described in the following

Graphs 1 and 2 demonstrate the instability of R.O.M.'s phonological system, who presented increasing use of some phonological processes in the Imitation Task (Wertzner, 2000) in the 2004 evaluation, such as palatal backing and fricative and plosive devoicing. The increasing use of these processes occurred because R.O.M. was starting to produce the palatal fricatives and some voiced fricatives and plosives, and demonstrated in this phase great difficulty in establishing which production should be performed to imitate the target word of the evaluation. These difficulties were also observed in the spontaneous speech, but after four months significant improvements were verified in his phonological chart. It is important to stress that despite the changes verified from the phonology evaluation in 2004, the severity degree of the phonology disorder didn't change, remaining as a mild-moderate disorder, as observed by the Percentage of Correct Consonant - PCC (Graph 3). Nowadays, he produces systematically the archiphoneme $\{\mathrm{R}\}$ and the lateral liquid (/l/) in the spontaneous speech, and unsystematically the voiced fricative phonemes (/z/ e /v/), the plosives $/ \mathrm{b} /$ and $/ \mathrm{d} /$ and the devoiced palatal fricative (/S/). He produces in isolated activities, the voiced palatal fricative $(/ \mathrm{Z} /)$, the voiced plosive phoneme $(/ \mathrm{g} /)$ and the consonantal cluster with the group / l/ (only in /fl/, /bl/, /pl/). However, there is still a great difficulty in the production with the consonantal groups.

Even though presenting several difficulties, R.O.M. is becoming interested in informatics and, with the family support, acquired a computer and is being able to perform satisfactorily an activity that is pointing out an effective vocational future and a way of acquiring new knowledge. 
GRAPH 1. Imitation Task of ABFW Test.
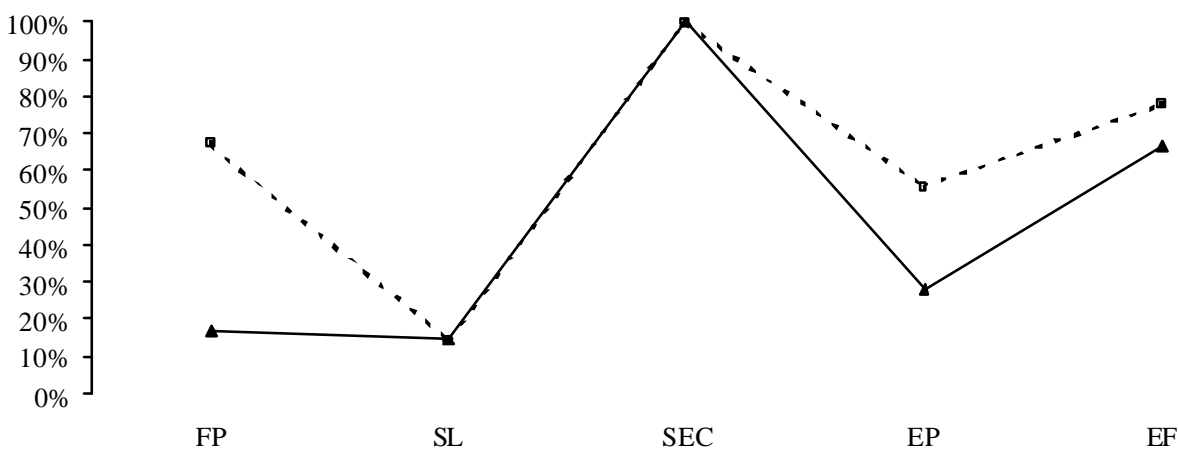

$\longrightarrow$ nov/03 - . - . mar/04

Legenda: FP = frontalização para palatal; SL = simplificação de líquidas; $\mathrm{SEC}=$ simplificação do encontro consonantal; EP = ensurdecimento de plosivas; $\mathrm{EF}=$ ensurdecimento de fricativas.

GRAPH 2. Naming Task of ABFW Test.

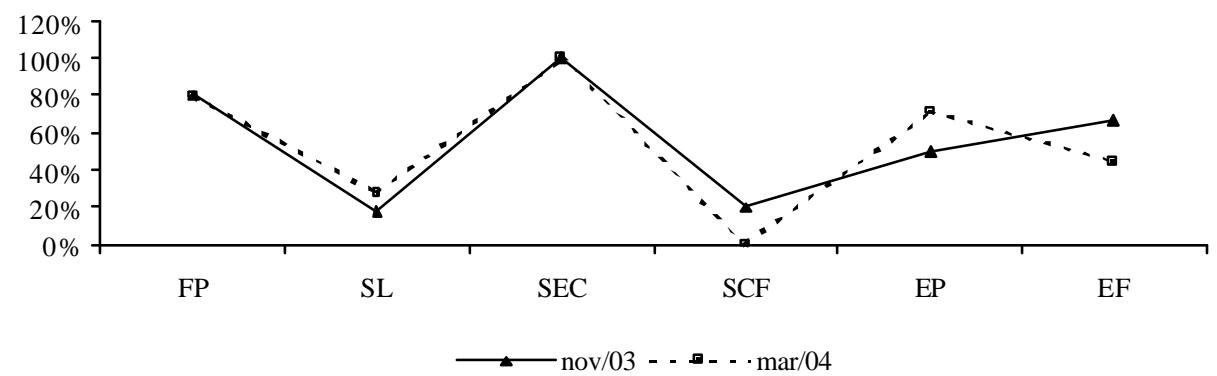

Legenda: FP = frontalização para palatal; $\mathrm{SL}$ = simplificação de líquidas; $\mathrm{SEC}=$ simplificação do encontro consonantal; $\mathrm{EP}=$ ensurdecimento de plosivas; $\mathrm{EF}=$ ensurdecimento de fricativas.

GRÁFICO 3 - PCC e PDI da Prova de Fonologia do Teste ABFW.

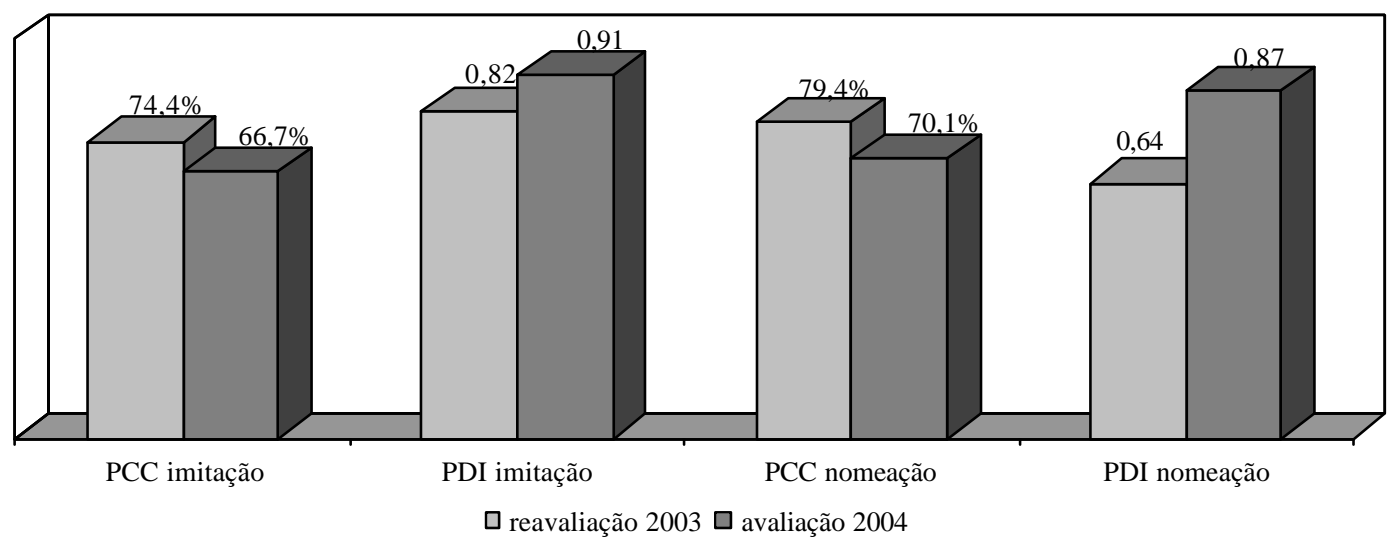

Legenda: $\mathrm{PCC}=$ porcentagem de consoantes corretas; PDI = índice de ocorrência de processos. 


\section{Discussion}

The description of the SLI includes the persistence of the communication disorders in the adolescence and the interference of language disorders in the social, cognitive, academic, communicative and behavioral skills acquisition and development (Catts et al., 2002, Laws \& Bishop, 2003). As described in the literature, R.O.M. was diagnosed during childhood and presented varying linguistic manifestations, modifying his linguistic profiles through the years and maintaining some difficulties, in oral language as in written language, until his actual age, even after speech-language intervention since three years old.

His scholar and academic performance are a result of the disorder persistence, since he still maintains deficits in the phonological processing tests (except in phonological memory) and in reading and writing (Stothard et al. 1998; Briscoe et al., 2001; Young et al., 2002) jeopardizing his scholar performance.

As described by Stothard et al. (1998) and Laws \& Bishop (2003), the greatest deficits present in the adolescence would be related to the expressive language and to the phonological processing.

From the literature information and our clinical experience, we believe it's possible to discuss some matters that we consider fundamental for the therapeutics of children with SLI.

Contrarily to the great number of researches about children with SLI, a little has been reported about adolescents with this disorder, implicating in a limitation of valid speech-language evaluations and treatments that do not neglect the language problems (actual or not) of these individuals, which could result in an incorrect diagnosis and therapeutic planning. This is clear when we verify the few studies about the prevalence of language disorders in adolescents, the few researches that report which intervention strategies are more effective and insufficient data about which goals we should emphasize during the rehabilitation process. The existence of only a few standardized tests for adolescents, or tests that are sensitive for their language deficits also make difficult the comparison between these subjects' performance with their normal peers, and the verification of linguistic patterns that reached a reasonable level, as well as the therapeutic monitoring.

Furthermore, a few speech-language pathologists follow the same subject with SLI for several years and many of them can not predict what will happen with his social, academic and linguistic future. Therefore, the importance of longitudinal studies about SLI must be stressed so that speech pathologists can better predict, from the data obtained in the preschool phase, these individuals' performance in the adolescence and adulthood. Thus, a rehabilitation process could be planned, together with other professionals, aiming at better vocational, economic and personal opportunities for the adolescents with SLI.

The language therapy with adolescents with SLI must emphasize strategies and techniques that facilitate the individual's learning, so that these skills may be generalized more easily for the daily use. The adolescent must participate in the planning of his own rehabilitation process, identifying which behaviors are hindered and which are important for him, and providing examples of situations in which the strategies learned can be used, training, therefore, his pragmatics, metalinguistic and metacognitive abilities. This type of involvement may also reduce the motivation problems that are quite frequent in adolescents with SLI, as reported by Beitcham et al (2001) and Conti-Ramsden \& Botting (2004).

The therapeutic goals must emphasize the functional communicative abilities in order to promote better interaction and social acceptance and to provide higher chances for the academic and personal success. These skills must be learned and practiced in several interaction situations, resulting in greater security and motivation and, therefore, reducing the probability of emotional difficulties, social isolation and behavior problems, as demonstrate some studies (Redmond \& Rice, 2002; Conti-Ramsden \& Botting, 2004). Furthermore, the activities planning must consider the linguistic stage in which the adolescent is, and the proposed activities must be determined from his cognitive and social level. 


\section{Conclusion}

Even considering that it is not possible to generalize from a case study, we intended to demonstrate to speech-language therapists that the difficulties presented by individuals with SLI are not restricted to the oral language or to children, once they remain presenting language and learning problems with educational and social consequences for the whole life. However, at the same time, we tried to stress all development potential of these children, and that with the proper assistance and active participation of the subject, this population's expectations may be broadened in a significant way. 


\section{References}

ANDRADE, C. R. F. de.; BEFI-LOPES, D. M.; FERNANDES, F. D. M.; WERTZNER, H. F. ABFW - teste de linguagem infantil: nas áreas de fonologia, vocabulário, fluência e pragmática. Barueri: Pró-Fono, 2000.

ARAM, D. M.; EKELMAN, B. L.; NATION, J. E. Preschoolers with langague disorders: 10 years later. $J$. Speech Lang. Hear Res., v. 27, n. 2, p. 232-244, jun. 1984.

BEFI-LOPES, D. M. Aspectos da competência e do desempenho lexicais em crianças entre 4;0 e 6;6 anos, com padrões de desenvolvimento normal e com alterações articulatórias. 1997. 285 f. Tese (Doutorado em Semiótica e Lingüística Geral) - Universidade de São Paulo, São Paulo. BEFI-LOPES, D. M. Vocabulário. In: ANDRADE, C. R. F. de.; BEFI-LOPES, D. M.; FERNANDES, F. D. M.; WERTZNER, H. F. ABFW - teste de linguagem infantil: nas áreas de fonologia, vocabulário, fluência e pragmática. Barueri: Pró-Fono, 2000. cap. 2.

BEFI-LOPES, D. M. Prova de verificação do vocabulário: aspectos da efetividade como instrumento diagnóstico. 2002. 146 f. Tese (Livre-Docência Departamento de Fisioterapia, Fonoaudiologia e Terapia Ocupacional) Universidade de São Paulo, São Paulo.

BEFI-LOPES, D. M. Avaliação, diagnóstico e aspectos terapêuticos nos distúrbios específicos de linguagem. In: FERREIRA, L. P.; BEFI-LOPES, D. M.; LIMONGI, S. C. O. Tratado de Fonoaudiologia. São Paulo: Roca, 2004. cap. 79 , p. 987-1000.

BEFI-LOPES, D. M.; PALMIERI, T. Análise dos processos fonológicos utilizados por crianças com alterações no desenvolvimento da linguagem. $J B F$, v. 1 , n. 4, p. 48-58, 2000.

BEFI-LOPES, D. M.; TAKIUCHI, N.; ARAÚJO, K. Avaliação da maturidade simbólica nas alterações de desenvolvimento da linguagem. $J B F$, v. 1, n. 3, p. 6-15, 2000a.

BEFI-LOPES, D. M.; TAKIUCHI, N.; ARAÚJO, K. Maturidade simbólica e linguagem - estudo follow-up. In: SOCIEDADE BRASILEIRA DE FONOAUDIOLOGIA. Atualização em Voz, Linguagem, Audição e Motricidade Oral. São Paulo: Frontes, 2000b. p. 1-15.

BEFI-LOPES, D. M.; RODRIGUES, A.; ROCHA, L. C. Habilidades lingüístico-pragmáticas em crianças normais e com alterações de desenvolvimento de linguagem. Pró-Fono Revista de Atualização Científica, v. 16, n. 1, p. 57-66, jan.-abr. 2004.

BEITCHAM, J. H.; WILSON, B.; JOHNSON, C. J.; ATKINSON, L.; YOUNG, A.; ADLAF, E.; ESCOBAR, M.; DOUGLAS, L. Fourteen-year follow-up of speech/languageimpaired and control children: psychiatric outcome. J.Am. Acad. Child. Adolesc. Psychiatry, v. 40, n. 1, p. 75-82, jan. 2001.

BISHOP, V. M.; CHAN, J.; ADAMS, C.; HARTLEY, J.; WEIR, F. Conversational resposnses in specific language impairment: evidence of disproportionate difficulties in a subset of children. Dev. Psychopathol, v. 12, n. 2, p. 177-199, 2000.
BISHOP, V. M.; CLARKSON, B. Written language as a window into residual language deficits: a study of children with persistent and residual speech and language impairments. Cortex, v. 39, n. 2, p. 215-237, apr. 2003.

BRISCOE, J.; BISHOP, V. M.; NORBURY, C. F. Phonological processing, language and literacy: a comparision of children with mild-to-moderate sensorineural hearing loss and those with specific language impairment. J. Child. Psychol. Psychiatry, v. 42, n. 3, p. 329-340, mar. 2001.

BOTTING, N.; FARAGHER, B.; SIMKIN, Z.; KNOX, E.; CONTI-RAMSDEN, G. Predicting pathways of specific language impairment: what differentiates good and poor outcome? J. Child. Psychol. Psychiatry, v. 42, n. 8, p. 1013-1020, nov. 2001.

CASTRO-REBOLLEDO, R. C.; GIRALDO-PRIETO, M.; HINCAPIÉ-HENAO, L.; LOPERA, F.; PINEDA, D. A. Transtorno del desarollo del languaje: una aproximación teórica a su diagnóstico, etiologia y manifestaciones clínicas. Rev. Neurol., v. 39, n. 12, p. 1173-1181, 2004.

CATTS, H. W.; FEY, M. E.; TOMBLIN, J. B.; ZHANG, X. A longitudinal investigation of reading in children with language impairments. J. Speech Lang. Hear. Res., v. 45, n. 6, p. 1142-1157, dec. 2002.

CONTI-RAMSDEN, G.; BOTTING, N.; SIMKIN, Z.; KNOX E. Follow-up of children attending infant language units: outcomes at 11 years of age. Int. J. Lang. Commun. Disord., v. 36 n. 2, p. 207-219, apr.-jun. 2001.

CONTI-RAMSDEN, G.; BOTTING, N. Social difficulties and victimization in children with SLI at 11 years of age. $J$. Speech Lang. Hear. Res., v. 47, n. 1, p. 145-161, feb. 2004.

CRESPO-EGUÍLAZ, N.; NARBONA, J. Perfiles clínicos evolutivos y transiciones em el espectro del transtorno específico del desarrollo del lenguaje. Rev. Neurol., v. 36, n. 1, p. 29-35, 2003.

FERNANDES, F. D. M.; ANDRADE, C. R. F. de.; BEFILOPES, D. M.; WERTZNER, H. F. Manual de avaliação de linguagem do serviço de Fonoaudiologia do centro de saúde escola Samuel B. Pessoa. Publicação Interna, 50 f., São Paulo, 1998.

GANDARA, J. P. The efficacy of treatment for children with developmental speech and language delay/disorder: a meta-analysis. Resenha de: LAW, J.; GARRET, Z.; NYE, C. J. Speech Lang. Hear. Res., v. 47, n. 4, p. 924-943, 2004. [comentada por: Juliana Perina Gândara].

JEROME, A. C.; MARTIN, F.; BRINTON, B.; JAMES, S. L. Self-esteem in children with specific language impairment. J. Speech Lang. Hear. Res., v. 45, n. 4, p. 700-714, aug. 2002.

JOHNSON, C. J.; BEITCHMAN, J. H.; YOUNG, A.; ESCOBAR, M.; ATKINSON, L.; WILSON, B.; BROWNLIE, E. B.; DOUGLAS, L.; TABACK, N.; LAM, I.; WANG, M. Fourteen-year follow-up of children with and without speech/language impairment: speech/language stability and outcomes. J. Speech Lang. Hear. Res., v. 42, n. 3, p. 744-760, jun. 1999. 
LAWS, G.; BISHOP, D. V. A comparison of language abilities in adolescents with Down syndrome and children with specific language impairment. J. Speech Lang. Hear. Res., v. 46, n. 6, p. 1324-1339, dec. 2003.

LINS, L.; BRAGA, S. M. L. Manual de avaliação de linguagem do serviço de Fonoaudiologia do centro de saúde escola Samuel B. Pessoa. Publicação Interna, 127 f., São Paulo, 1985.

NATHAN, L.; STACKHOUSE, J.; GOULANDRIS, N.; SNOWLING, M. J. Educational consequences of developmental speech disorder: key stage 1 national curriculum assessment results in english and mathematics. Br. J. Educ. Psychol., v. 74, n. 2, p. 173-86, jun. 2004a.

NATHAN, L.; STACKHOUSE, J.; GOULANDRIS, N.; SNOWLING, M. J. The development of early literacy skills among children with speech difficulties: a test of the "critical age hypothesis". J. Speech Lang. Hear. Res., v. 47, n. 2, p. 377-391, apr. 2004b.

REDMOND, S. M.; RICE, M. L. Stability of behavioral ratings of childrem with SLI. J. Speech Lang. Hear. Res., v. 45, n. 1, p. 190-201, feb. 2002.

RICE, M. L.; TOMBLIN, J. B.; HOFFMAN, L.; RICHMAN, W. A.; MARQUIS, J. Grammatical tense deficits in children with SLI and nonspecific language impairment: relationships with nonverbal IQ over time. J. Speech Lang. Hear. Res., v. 47, n. 4, p. 816-34, aug. 2004.

RODRIGUES, N. Avaliação das praxias motoras. In: RODRIGUES, N. Neurolingüística dos distúrbios da fala. São Paulo: Cortez - EDUC, 1999. apêndice 2, p. 181-191. SNOWLING, M.; BISHOP, D. V. M.; STOHARD, S. E. Is preschool language impairment a risk factor for dyslexia in adolescence? J. Child. Psychol. Psychiatry, v. 41, n. 5, p. 587-600, jul. 2000.
STOTHARD, S. E.; SNOWLING, M. J.; BISHOP, D. V.; CHIPCHASE, B. B.; KAPLAN, C. A. Language-impaired preschoolers: a follow-up into adolescence. J. Speech Lang. Hear. Res, v. 41, n. 2, p. 407-18, apr. 1998.

TAKIUCHI, N. Grammaticality sensitivity in children with early focal brain injury and children with specific language impairment. Resenha de: WULFECK, B.; BATES, E.; KRUPA-KWIATKOWSKI, M.; SALTZMAN, D. Brain Lang., v. 88, n. 2, p. 215-228, 2004. [comentada por: Noemi Takiuchi].

WATKINS, R. V. Specific language impairments in children - na introduction. In: WATKINS, R. V.; RICE, M. L. Specific language impairments in children. Baltimore: Paul $\mathrm{H}$. Publishing Co., 1994. p. 1-16.

WERTZNER, H. F. Articulação: aquisição do sistema fonológico dos 3 aos 7 anos. 1992. 280 f. Tese (Doutorado em Semiótica e Linguiística Geral) - Universidade de São Paulo, São Paulo.

WERTZNER, H. F. Fonologia. In: ANDRADE, C. R. F. de.; BEFI-LOPES, D. M.; FERNANDES, F. D. M.; WERTZNER, H. F. ABFW - teste de linguagem infantil: nas áreas de fonologia, vocabulário, fluência e pragmática. Barueri: Pró-Fono, 2000. cap. 1.

WERTZNER, H. F.; GALEA, D. E. S. Porcentagem de consoantes corretas - revisada (PCC-R) e índice de densidade fonológica (PDI) na aquisição fonológica. Rev. $S B F a$, v. 6 , n. 1 , p. 44-50, jun. 2002.

WERTZNER, H. F.; HERRERO, S.; IDERIHA, P. N.; PIRES, S. C. F. Classificação do distúrbio fonológico por meio de duas medidas de análise - porcentagem de consoantes corretas (PCC) e índice de ocorrência dos processos (PDI). Pró-Fono Revista de Atualização Científica, v. 13, n. 1, p. 90-97, 2001.

YOUNG, A. R.; BEITCHMAN, J. H.; JOHNSON, C.; DOUGLAS, L.; ATKINSON, L.; ESCOBAR, M.; WILSON, B. Young adult academic outcomes in a longitudinal sample of early identified language impaired and control children. J. Child. Psychol. Psychiatry, v. 43, n. 5, p. 635-645, jul. 2002. 